\title{
The Stela of $s 3-w 3 d-h 3 t$ Preserved in the Grand Egyptian Museum with No.GEM 14376 "A Comparative Analytical Study and Publishing for the First Time"
}

\section{The Stela of $s 3-w 3 d-h 3 t$ Preserved in the Grand Egyptian Museum with No.GEM 14376 "A Comparative Analytical Study and Publishing for the First Time"

\author{
Basem Mohamed Khatab. \\ Department of Ancient Egyptian Archaeology, Faculty of Archeology and Tourism \\ Guidance, Misr University for science and Technology . \\ basem.khattab@must.edu.eg/ bassemkhatab2020@gmail.com
}

\begin{abstract}
This study aims to discuss and study a stela of published before, and which has neither been investigated nor studied in a comprehensive analytical study by researchers. a stela has a semi-circle top that may be an imitation of the planetarium or Primeval mound. This a stela is preserved in the Grand Egyptian Museum with NO. GEM 14376. A stela contained five registers containing recorded texts and scenes, At the top and the top of turning, the formula for making the offerings is inscribed in one clear line that continues in the first register. The main scenes depicting the children and relatives of the deceased (owner) are inscribed in the second, third, and fourth registers. The stela ends with one writing line in the fifth register. The present study covers the stela analytically, linguistically, and technically according to the descriptive, analytical, and comparative approach. It examines the linguistic structures and analyzes the technical elements of the stela and their symbolism in ancient Egyptian beliefs. Furthermore, it applies the comparative historical approach to the technical elements and linguistic connotations to accurately date the stela under study.
\end{abstract}

Keywords: Stela of $s 3-w 3 \underline{d}-\underline{h} 3 t$, the Grand Egyptian Museum, Offerings, Lotus, kilt symbolism.

\section{Introduction}

In ancient Egypt, a stela is a memorial mostly made of different materials, such as stone or wood(Shoukry, 1958, Martin,1986, Hölzl,2001). Its height was often longer than width. It was created and dedicated to fulfilling some purposes or political events, such as the boundary stela, memorial purposes to commemorate an event, funeral purposes to commemorate the deceased, such as stela $S 3-w\} \underline{d}-\underline{h} 3 t$ understudy, as well as many other purposes. Stelae were often decorated with different scenes in terms of type and shape, as well as the type of inscriptions(Müller,1933, Hermann,1940) . 
The present study is significant because it covers an unpublished funeral stela of 18 " S3-w3 3 Museum. It adopts the comparative descriptive, analytical, and historical approach to examine the technical aspects, phonetic values, and linguistic connotations. Furthermore, it examines the stela analytically for accurate dating based on the technical manifestations and linguistic and historical features of other similar funeral stelae at the time. Therefore, the study examines the rectangular stela with a semi-dome top and the scenes and technical elements. Analyzing the phonetic values, linguistic connotations, and writing features of the inscribed texts shows that the stela dates back to the late $12^{\text {th }}$ and early $13^{\text {th }}$ dynasties.

2. Descriptive Study of Stela $183-w 3 \underline{d}-\underline{h} 3 t)$ GEM 14376 (Figure 1)

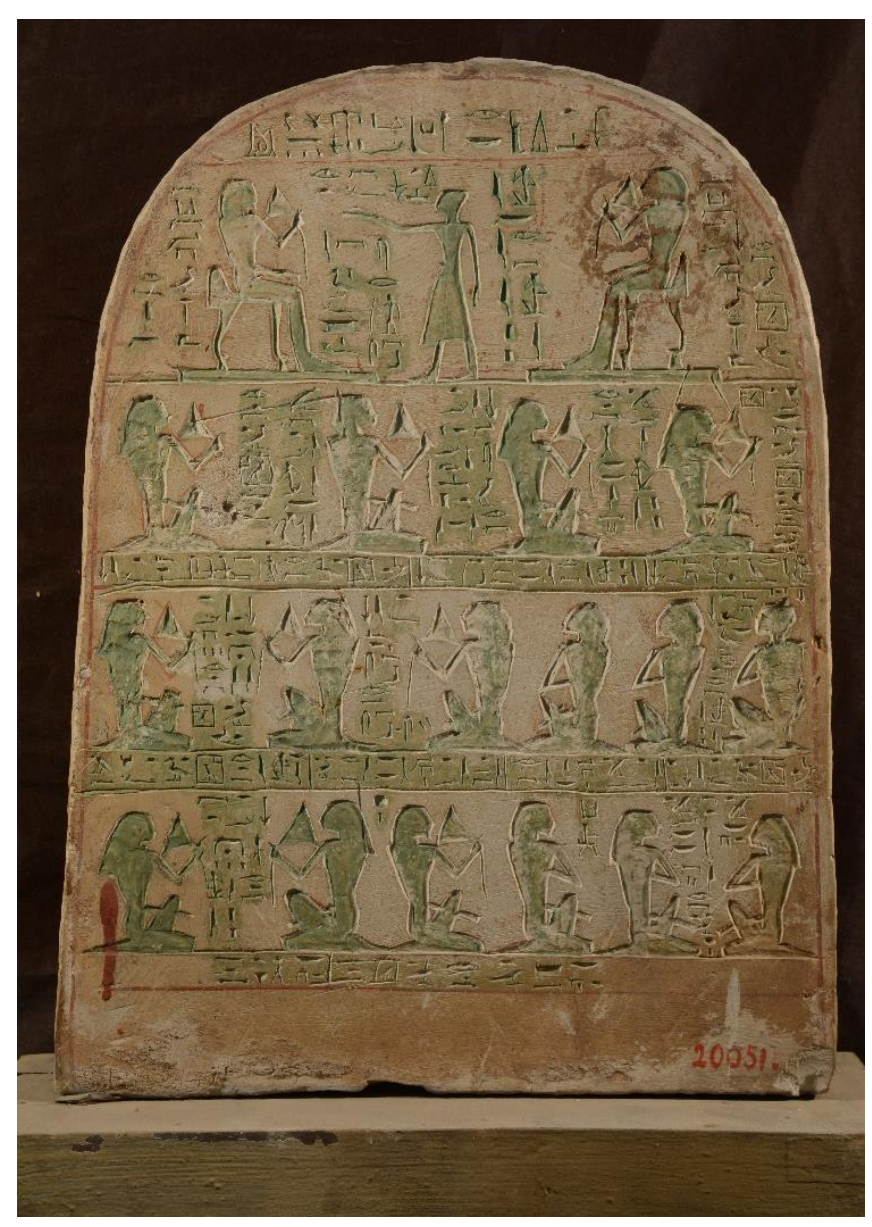

Fig. (1): Stela $s 3-w 3 \underline{d}-\underline{h} 3 t$ (by the author) 
The Stela of $s 3-w 3 d-h 3 t$ Preserved in the Grand Egyptian Museum with No.GEM 14376 "A Comparative Analytical Study and Publishing for the First Time"

2.1. Owner: According to the inscriptions regestred on the stela, it belongs to \} 为 $S 3-w 3 \underline{d}-\underline{h} 3 t$.

2.2. Shape: the stela is a colorful rectangular stela with a circular top.

2.3. Appearance and content: The stela is colorful and includes some technical elements and linguistic connotations. It is divided into four registers. At the top and the top of turning, the formula for making the offerings is inscribed in one clear line that continues in the first register. The main scenes depicting the children and relatives of the deceased (owner) are inscribed in the second, third, and fourth registers. The stela ends with one writing line in the fifth register

2.4. Material: Colored limestone.

2.5. Dimensions: The stela measures $42.4 \mathrm{~cm}$ hight, $29 \mathrm{~cm}$ width, and $6-5 \mathrm{~cm}$ thickness (diameter).

2.6. Location of discovery: The stela was found in ancient Egyptian Nome VIII $(t 3-w r)$ in the region of Abydos, Sohag governorate.

2.7. preservation location and register number: The Grand Egyptian Museum numbered (GEM 14376).

2.8. conservation status: It is is preserved in good condition.

3. Linguistic Study of the Inscribed Texts on Stela $S 3-w 3 \underline{d}-\underline{h} 3 t$ (GEM 14376)

It is noted that the texts were distributed according to the technical division adopted by the ancient Egyptian artist who created the stela. This method might be necessary to explain the scenes and to highlight the aesthetic value of the stela that was completed by distributing texts, as follows:

- The top of turning contains one writing line horizontally, which is the main text that contains the formula for making the offerings completed in lines 2 and 3, as follows:

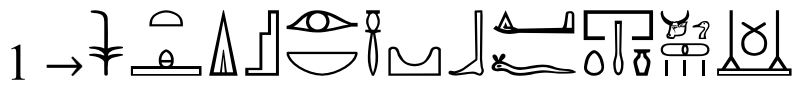

htp-di-nsw Wsir nb 3bd्dw di.f prt-hrrw thnkt k3w 3pdw šs mnht

"An offering given by the king (to/and) Osiris lord of Abydos to make an offering orally (by supplication) of bread, beer, oxen, birds, alabaster, and linen". 
- The First Register: To the left of the observer, the owner of the stela is depicted looking to the right and sitting on a chair with lion legs and a short cushion on a step higher than the ground level. He wears a short wig, a pointed chin, and a short kilt. He puts his left hand on the knee and holds a Lotus by the right hand, making it close to the nose. In the back, there are two horizontal lines to complete the formula of making the offering inscribed at the top, as follows:

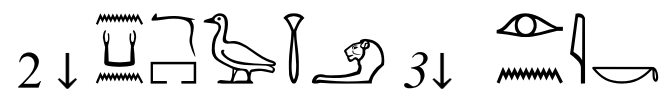

$n$ k3 n imy-r pr s3-w3d-h3t (Ranke, 1931) ir.n ik (Ranke, 1931)

"To the soul of the householder $S 3$ w3 $\underline{d} \underline{h} 3 t$ born by $i k$ ".

In the middle, the son of the owner snb is depicted standing, looking at his father, raising his right hand, and dedicating offerings to him. He wears a long kilt tied with a knotted belt from the front. Above, the text is written in a horizontal line (4) and is completed in two vertical columns ( $5 \& 6$ ), as follows

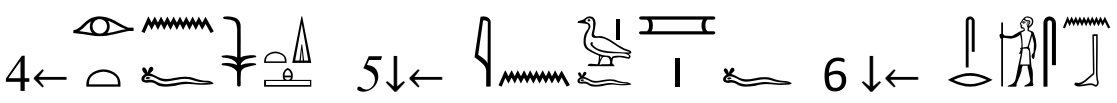

irt n.f htp-di-nsw in s3.f mry.f sr snb (Ranke, 1931)

"Who gave royal offerings by his son and beloved snb".

Behind the son, a text is registered in a vertical column (7) that reads

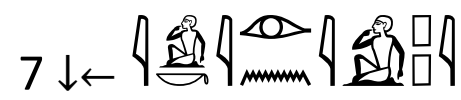

iki (Ranke, 1931) ir.n ippi (Ranke, 1931)

"O iki born of (the son of) ippi"

On the right side of the first register, the son of the owner was depicted in a form almost close to his brother looking to the left. Behind, a text is in two vertical columns $(8 \& 9)$, indicating that the offerings were given to him, as well. It reads

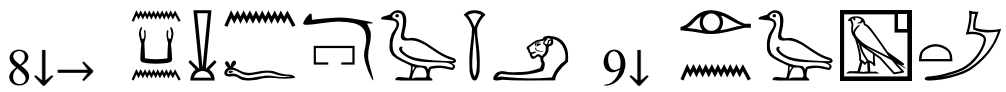

$n k 3$ n sn.f imy-r pr s3 w3 $\underline{d}$ ḩ3t ir.n s3(t) Hwt- Hr m3t (Ranke, 1931)

"To the soul of his brother the householder "s3 w3d h3t" son of "s3(t) Hwt-Hr m3t". 
The Stela of $s 3-w 3 d-h 3 t$ Preserved in the Grand Egyptian Museum with No.GEM 14376 "A Comparative Analytical Study and Publishing for the First Time"

\section{The second register}

On the right side, a lady may be the wife of the owner. She sits looking to the right and holds a Lotus. In front, a text in two vertical columns (10 \& 11) reads

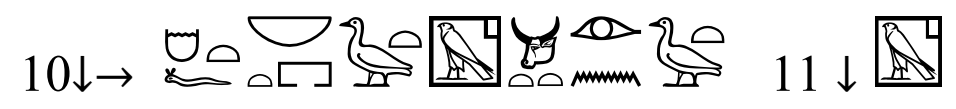

hmt.f nbt pr s3t Hwt- Hr hntt (Ranke, 1931) ir.n s3t Hwt- Hr

His wife is the housewife "s3t Hwt- $\mathrm{Hr}$ hntt" daughter of "s3t $H w t-H r$ "

In front of the other lady who also sits on the ground and holds a Lotus, a text in two vertical columns $(12 \& 13)$ reads

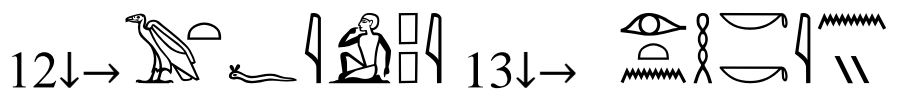

mwt.f ippi (Ranke, 1931) irt.n ḥkkiny (Ranke, 1931)

His mother is Ippi daughter of "hkkiny"

In the middle, a person who may be the uncle of the owner sits cross-legged and smiles a Lotus. In front, a text in a vertical column (14) reads

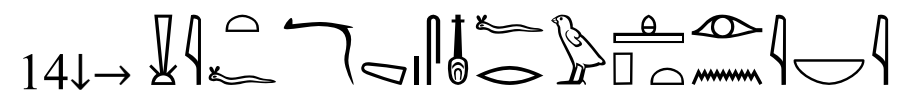

sn it imy-r 3h(w)t (Ward,1982) snfrw htp(Ranke, 1931) ir.n iki .

"A brother of his father (uncle) supervisor of the fields snfrw htp, son of $i k i "$

In the far left, a lady may be the grandmother of the owner sits and holds a Lotus. In front, a text in two vertical columns $(15 \& 16)$ reads

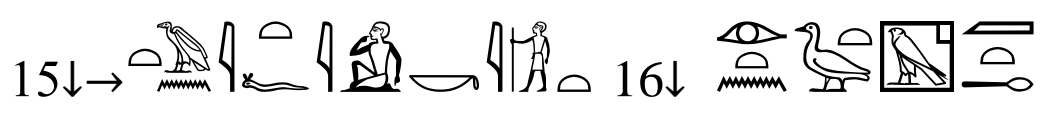

mwt n it.f iki irt.n s3t Hwt- $\mathrm{Hr} \mathrm{m}^{\mathrm{C}} \mathrm{t}$ hrw

"The mother of his father (grandmother)" $i k i "$ daughter of $s 3 t H w t-H r$ true of voice" 


\section{The Third register}

It starts with a text in a horizontal line above the third register from the left $(17,18$, and 19). It completes with a horizontal text above the head of the sitting man in the far left and reads

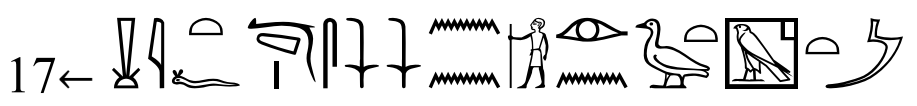

sn it.f imy-r 3h(w)t snn wr (Ranke, 1931) ir.n s3t Hwt- Hr m3t

"The brother of his father (uncle) supervisor of the fields "'snn wr" son of "s3t HwtHr m3t"

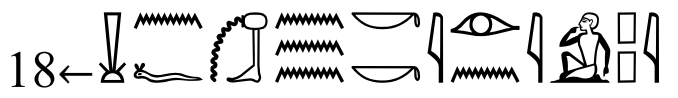

sn.f w`b kki (Ranke, 1931) ir.n ippi

"The brother of the priest "kki" son of "ippi"

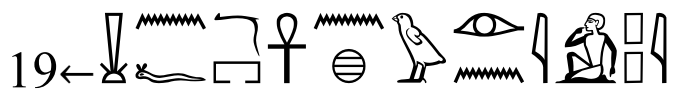

sn.f imy-r pr 'nhw ir.n ippi

"His brother is the supervisor of the house of Livings , son of "ippi"

On the left side, a text in a vertical column between the two sitting ladies reads

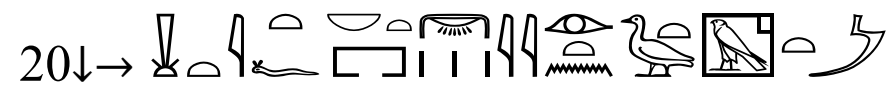

snt it.f nbt-pr nwbwy irt.n s3t Hwt- Hr m3t

"The daughter of his father (his aunt) the housewife "nwbwy" daughter of "s3t HwtHr m3t"

In the middle of the register, a text in a vertical column in front of the lady no. (3) from the left reads

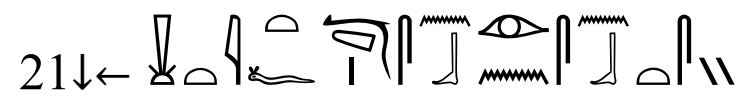

snt it.f imy-r 3ḥ(w)t snb ir.n snb tisy(Ranke, 1931). 
The Stela of $s 3-w 3 d-h 3 t$ Preserved in the Grand Egyptian Museum with No.GEM 14376 "A Comparative Analytical Study and Publishing for the First Time"

"The daughter of his father (his aunt) the supervisor of fields "snb" born of "snb tisy"

On the right side, a text in a vertical column in front of a sitting man reads

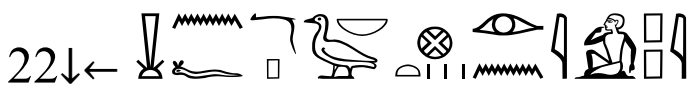

sn.f imy-r pr s3 nb niwwt ir.n ippi

"His brother, the supervisor of the house, is the son of the cities lord "ippi".

\section{The fourth register}

It starts with a text in a horizontal line above the fourth register from the left (23, 24,25 , and 26) that reads

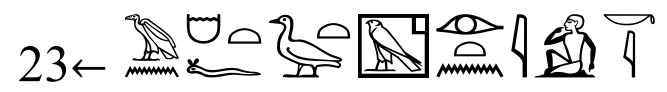

mwt n ḥmt.f s3t Ḥwt- Hr irt.n iki

"The mother of his wife (mother-in-law) "s3t Hwt- Hr" daughter of "iki"

It is noted that this statement (24) reads from right to left and continues behind the lady no. (2) from the left.

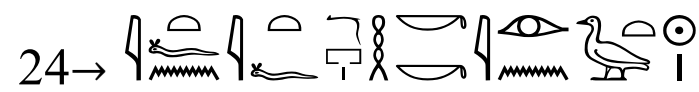

it $n$ it.f imy-r pr hkki (Ranke, 1931) ir.n s3t $R^{\complement}$ (Ranke, 1931)

"The father of his father (grandfather) "Hkki" the supervisor of the house son of "s3t $R^{c \prime \prime}$

It is noted that the statement (25) that starts from the right to the left, continues in front of the person no. (3) from the right, reads

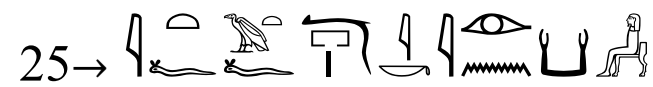

it mwt.f imy-r3 pr iki ir.n k3 (Ranke, 1931). 
"The father of his mother (grandmother) the supervisor of the house "iki" son of $" k 3 "$

$26 \leftarrow$ 政?

hmt sn it.f s3t Hwt- $\mathrm{Hr} m 3 t$

"The wife of his father's brother (aunt) $s 3 t \mathrm{Hwt}-\mathrm{Hr} m 3 t "$

On the right side, a text in a vertical column reads

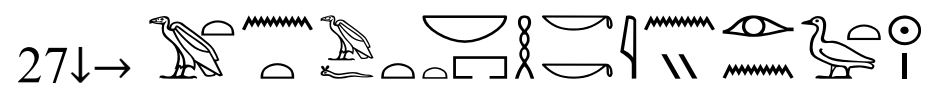

mwt nt mwt.f nbt pr hlkk iny ir.n s3t-Re

"The mother of his mother (grandmother) housewife " hkk iny " daughter of " s3t-Re $"$

On the right side, a text in a vertical column reads

$28 \downarrow \rightarrow$ t

snt.f nit hạdt (Ranke, 1931) irt.n ippi

"His sister "nit hạ" born of "ippi"

\section{The fifth register}

It has one horizontal line only starting from the right. It seems that the artist was satisfied with that line or the remaining area of the stelae did not allow depicting the other family members as in the previous registers. The text reads

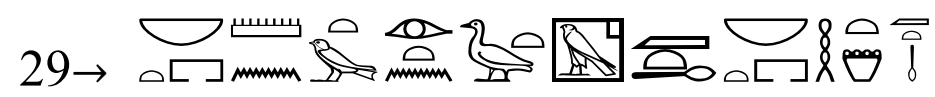

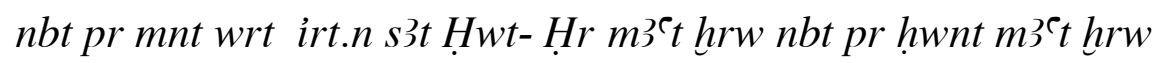

The housewife "mnt wrt" daughter of "s3t Hwt- Hr" true of voice. The housewife hwnt true of voice " . 
The Stela of $s 3-w 3 d-h 3 t$ Preserved in the Grand Egyptian Museum with No.GEM 14376 "A Comparative Analytical Study and Publishing for the First Time"

\section{A comparative analytical Study of the formulas and texts registered on the stela.}

\section{1. htp di nsw formula registered on the stela:}

The formula for making the offerings htp di $n s w$ at the top of the stela is inscribed horizontally $\Delta_{\Theta} \neq$ from right to left. Comparing it to the formulas for making offerings mentioned by Barta shows the prevalence of this form of writing in several formulas(Barta,1968). Similarly, a comparison with the formulas reported in CG shows the prevalence of this formula since the Old Kingdom "Compare the Stelae of the Egyptian Museum in: Catalogue général des antiquités égyptiennes du Musée du Caire, Le Caire (CG 20023, 20027, 20034, 20059, 20100, 20122, 20142, 20145, 20198,20255, 20393, 20596, 20608, 20612, 20660,20709, 20730".Bennett reports similar texts in this writing from the early $4^{\text {th }}$ dynasty to the Ptolemaic and Roman eras in the linguistic structures of making offerings and adds that this was one of the most common formulas in the Middle and New Kingdoms of Egypt(Bennett,1941). Furthermore, Smither argues that there were other similar formulas like the one under study was one of the most common on the stelae of the Middle and Modern Kingdoms, in general. However, comparing the horizontal inscriptions and the method of writing shows that this formula was common in the stela of the Old Kingdom to the late 13th dynasty (Smither,1939) .

\subsection{The writing forms significance of the God Wsir's name and titles on the stela:}

The name of the god Wsir was inscribed as $]^{\infty}$. It is noted that there is a projection of the deity 1 was that common in the since the time of king Amenemhat III as shown by the study of Bennet who reported that the stelae dated to the reign of Amenemhat III did not have a dedication of the deity (Bennett,1941). A comparison with stela "hrw-nfr" dated back to the reign of Amenemhat III of the Middle Kingdom shows the prevalence of writing the name $n b 3 b \underline{d} w$ as shown in the stela without a dedication of the deity(Metawi,2008). The title of the deity " $n b 3 b \underline{d} w$ " was written symbol of the city " in the formulas of the Old and Middle Kingdoms."Compare with CG 20023, 20027, 20034, 20059, 20100, 20122, 20142, 20145, 20198,20255, 
20393, 20596, 20608, 20612, 20660,20709, 20730".(Bennett,1941; Barta,1968). In

the stela understudy, it was mentioned as city "ख". This method dominated the 13th dynasty as was illustrated in many stelae of the time.Compare with.CG.20023,20142, 20700, 20687, 20660, 20353.( Hein\& Satzinger,1989).

\subsection{The Place of Discovering the Stela and the Significance of its Relation to the God Osiris}

The stela was found in Abydos- Sohag- the $8^{\text {th }}$ nome of Upper Egypt that was called $t 3-w r$ in ancient Egypt. The name $t 3-w r$ was first found in the texts of the Universe Chamber, Sun Temple of Nyuserra in Abu Ghurab and the tomb on Nswt$\operatorname{Nefr}($ Helck,1977 ). It was also found in the pyramid texts that reported that this was the holy place of Osiris(Wb,1957). In later periods, it was known as tny-one of its most important cities was Abydos that was mentioned in the coffin texts as the official headquarter of Osiris, whereas the sky was the official headquarter of $\mathrm{Ra}$ (Wazery,2009). possibly because Osiris was killed near Abydos(Griffiths ,1970). Abydos was the gate of the righteous people to the Otherworld(Wazery,2009). It is worth noting that $t 3-w r$ means the great or ancient land(Otto, ${ }^{1975)}$. Although scholars agreed on the symbolism and connotation of the symbol and name(Wazery,2009), most of the opinions related it to the god Osiris and Abydos site (Mariette, 1880 ; Legrain, 1916 ; Winlock,1921)

\subsection{Prt-hrw syntax registered on the stela}

Prt-hrw was mentioned after di.f to mean "he makes offerings"(Bennett,1941). It was common since the 12th dynasty onwards. Compare with. CG.20121,20092, 20589,20227(Mariette,1880, Lang \& Schäfer,1902, Tomich, 2017) . It was found in some stelae in the First Intermediate Period, such as the stela of xwy dated back to the late First Intermediate Period

(El-Khadragy,1999) .

According to the study of Bennett that covered 121stelae of the Middle Kingdom, this formula was reported alone in the $11^{\text {th }}$ dynasty (Bennett,1941).

\section{5. šs mnht syntax registered on the stela}

šs mnht was common in the formula of making offerings in the Middle Kingdom. It was inscribed on the stela as $\stackrel{\lfloor\downarrow}{\zeta}$ but was not reported in this form in stelae before the era of Senusret III (Tomich,2011). except for one case in which it was reported 


\section{The Stela of $s 3-w 3 d-h 3 t$ Preserved in the Grand Egyptian Museum with No.GEM 14376 "A Comparative Analytical Study and Publishing for the First Time"}

as Ss between the sign mnxt in stela no. BM 567 dating back to year 13 of the reign of Amenemhat II according to the study of Tomich that included 243 stelae from Amenemhat I and Senusret II(Tomich, 2017).

\section{6. $k 3 w 3 p d w$ syntax registered on the stela}

$k 3 w 3 p d w$ was the most common statement after the word. It was often a predicate and beer $\triangle$ (Bennett,1941) It was found in various writing forms. In the stela under study, for example, it was used as 111 that was more common in the $13^{\text {th }}$ dynasty and continued in the second half of the First Intermediate Period (Shalaby \& Nassar,2018).

\subsection{The syntax of $n k 3 n$ registered on the stela}

The form of $n k 3 n \quad \underline{\square}$ was used in stela since the era of Senusret III owards (Bennett,1941), And by comparison with the stelae dating back to the late $12^{\text {th }}$ and the early 13th dynasties that preserved in Athens Museum (Stefanović, 2010) and preserved in Egyptian Museum.CG.20610(Franke,1984).

Concerning the name of the owner $S 3$ w $3 \underline{d} h 3 t$, Ranke argues that the name was reported in the Middle Kingdom (Ranke, 1931), as shown in the stela CG.20581(Franke,1984). The structure "ir.n" born by or son, was common before the name of the man and woman, especially in the texts of the $13^{\text {th }}$ dynasty (Selim,2001). Moreover, many names used since the Old and Middle Kingdoms were reported in the stela. For instance, ippi was introduced in the Middle

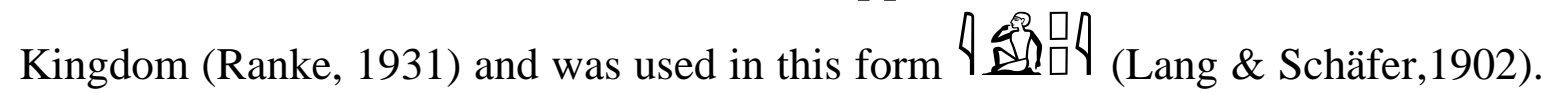
Ranke argues that the name $S n b$ was introduced in the Old Kingdom, prevailed in the Middle Kingdom, and continued in the New Kingdom. It was used in several

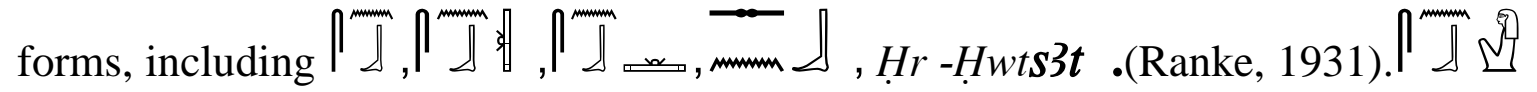
was used in the Middle Kingdom in the feminine form in several ways, such as

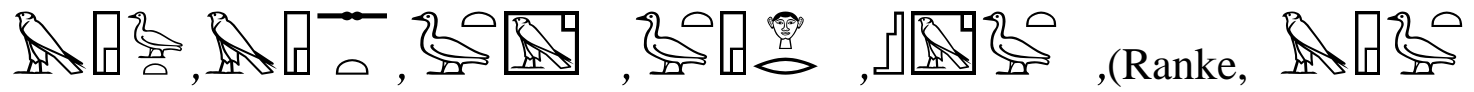
1931). $i k$ was introduced in the Middle Kingdom and the Second Intermediate 
Period in various forms, e.g., 4 (Ranke, 1931). It was used in other stelae in the same form.compare.CG.20030(Lang \& Schäfer,1902).

\section{Analytical Study of the Artistic Elements and Scenes of Stela $s 3-w 3 \underline{d}$ - $h 3 t$ and their Symbolism}

Some religious symbolic connotations are implied in the scenes of the stela understudy, as follows:

5.1. The top of the stela: It is round. This form was introduced in the $1^{\text {st }}$ dynasty(Vandier,195). It might be an imitation of the Primeval mound on which the creator deity appeared or influenced by the shrines of primitive deities. It might also be influenced by the shape of the tomb in Upper Egypt topped by a small pyramid or carved in stone with doomed rooms(Maspero,1908; Gardiner,1991).

\subsection{The Deceased and His Posture and Symbolism of Setting on the Seat}

The deceased was depicted sitting on a chair without a back with lion legs-shaped legs (Ragheb,1996), based on two high stands. Ritually, this conveys the prestige of the deceased sitting on the chair(Vercoutter and Castel,1978). It is thought that this setting ensures the protection of the lion and ensuring resurrection for eternal life in the Other World(Wilkinson,2007) . Moreover, this chair might dominate the Middle Kingdom but appear in the tombs of the $1^{\text {st }}$ and $2^{\text {nd }}$ dynasties(Fischer,1996). It appeared on some stelae dating back to the Early Dynastic Period (Saad,1957). It is argued that the legs were primarily like the legs of the bull and replaced with the lion legs since the $3^{\text {rd }}$ dynasty(Mahmoud,2005)

The sitting position was thought of as an intermediate stage between death and resurrection. The deceased is in about to stand position to take functions in the same manner as he was alive. It is the stage of transformation from death to eating offerings of food and suppliers to standing and resurrection (Radwan,2003).

5.3. Lotus and its Symbolism: The ancient Egyptian knew three types of the lotus: White lotus "š̌n"(Wb,1957), blue lotus "spt/s3pt"(Wb,1957), and the rare red/pink lotus " $n h b "(\mathrm{~Wb}, 1957)$. In the ancient Egyptian beliefs, the lotus was related to resurrection implied in its nectar that renews the sense of smell of the deceased. It often appeared in the ancient Egyptian scenes because it renewed the respiratory and sexual ability of the deceased and achieved resurrection in the Other World. Thus, the deceased wished to become a lotus to ensure resurrection and rebirth(Shalaby \& Nassar,2018). 


\section{The Stela of $s 3-w 3 d-h 3 t$ Preserved in the Grand Egyptian Museum with No.GEM 14376 "A Comparative Analytical Study and Publishing for the First Time"}

\subsection{Kilt and its Symbolism}

The kilt was the main gown of men. Westendorf argued that it played an effective role in the ancient Egyptian beliefs at it embedded the grip of god "Atom". Moreover, Leclant stressed this thought. In short, it enables the resurrection of the deceased (Westenddorf,1967).

\section{Results:}

The stela dates to the late $12^{\text {th }}$ and early $13^{\text {th }}$ dynasties because most of the stelae had round top and poor artistic level, which is clear in the scenes and inscriptions, such as depicting the relatives sitting and in a large number. Since the era of Amenemhat II, individuals were depicted holding lotus flowers to smell them . Moreover, the formula di.f prt hrw was used as it prevailed in the late $12^{\text {th }}$ and subsequent dynasties. The statement "క̌s mnht" was inserted as that prevailed $\underline{|\succ|}$ in the late $2^{\text {nd }}$ and subsequent dynasties, and the statement "k3w $3 p d w$ " was used as dynasty and continued in the second half of the thet was common in the 13 ii First Intermediate Period. Additionally, some letters, such as the Cursive font. It is suggested that the stela under study is a reference of a threegeneration family. The formula "ir. $n$ " was used to convey the relationship between the three generations. Additionally, many relatives were represented, such as the uncle, aunt, grandfather, and grandmother to indicate family bonding and the desire to commemorate the memory of the relatives and companionship in the Other World.

\section{List of Abbreviations}

- $\boldsymbol{A S A E}=\underline{\text { Annals du Service des Antiquités de L'Égypte, Le Caire. }}$

- $\boldsymbol{A U C}=$ American University in Cairo, Cairo.

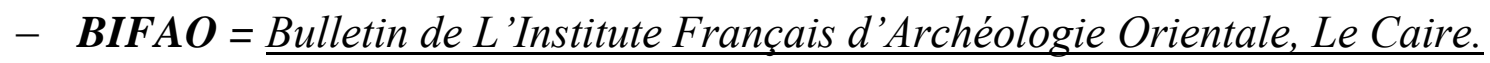

- $\boldsymbol{C G}=\underline{\text { Catalogue général des antiquités égyptiennes du Musée du Caire, Cairo. }}$

- IFAO = Institute Française d'Archéologie Oriental, Le Caire.

- JARCE = Journal of the American Research Center in Egypt, Boston.

- JEA = Journal of Egyptian Archaeology, London.

- $\boldsymbol{L} \ddot{\boldsymbol{A}}=\underline{\text { Helck}, W . \& \text { Otto, E., "Lexikon der Ägyptologie", } 7 \text { vols., Wiesbaden }}$ 1975-1986.

- MÄS = Münchner Ägyptologische Studien, Berlin. 
- MDAIK $=$ Mitteilungen des Deutschen Archäologischen Instituts, Abteilung Kairo, bis 1944: Mitteilungen des Deutschen Instituts für Ägyptische Altertumskunde. In Kairo, Berlin, Wiesbaden, ab 1970; Mainz.

- MIFAO = Mémoires publiés Par les membres de L'Institut Français d'Archéologie Orientale du Caire, Cairo.

- $\boldsymbol{S A E}=\underline{\text { Service des Antiquités de L'Égypte, Cairo. }}$

- SAK $=\underline{\text { Studien zur Altägyptischen Kultur, Hamburg. }}$.

- $\boldsymbol{W b}=$ Erman, E., \& Grapow, H., "Wörterbuch der ägyptischen Spache", 6 vols., Berlin-Leipzig, 1957.

\section{References}

- Barta, W. (1968). Aufbau und Bedeutung der altägyptischen Opferformel, Ägyptologische Forschungen Vol.24. Glückstadt,pp. pp. 4, 12, 21, 24, 36, 43, 45, 53, 55/3, 70, 72, 81, 85, 107, 139, 162, 172, 185-186, 194-195, 203, 209.

- Bennett, C. (1941). 'Growth of the htp di nsw in the Middle Kingdom and New Kingdom", JEA 27, 77-82.

- Brunner, T. E., "Blume", LÄ I, Cols. 836-839.

- El-Khadragy, M. (1999). "A late First Intermediate Period Stela of the Estate Manager Khuy", SAK 27, pp. 223-231.

- Erman, E., \& Grapow, H., "Wörterbuch der ägyptischen Spache", 6 vols., BerlinLeipzig, $\quad$ 1957,Vol.I,P.177/7-8,211/7,398/15, Vol.II, 307/34,vol.III,487/9, vol.IV.18/5-6,vol.v,222.

- Fischer, H. (1996). A Chair of the Early New Kingdom, Egyptian Studies III, Varia Nova, New York, pp.146-149.

- Franke ,D.(1984). Personendaten aus dem Mittleren Reich (20.-16. Jahrhundert v. Chr.), V 41, Wiesbaden, D45,pp. 317, Doss 522, 365, Doss 617,

- Gardiner, A (1991). Egyptian Grammar, Third Edition, Oxford, O.20.

- Griffiths., J. G., (1970). Plutarchs De Isido et Osiride, Cambridge, p. 341.

- Hein, I., \& Satzinger, H. (1989). Stelen des Mittleren Riches I, Einschließlich Der I und II, Mainz, pp.39-43.

- Helck., W., "Gaue", LÄ II, 1977, col., 388.

- Hermann, A. (1940). Die Stelen der Thebanischen Felsgraber der 18 Dynastie, In: Agyptologische Forschungen 11, (Gluckstadt),p.32. 
The Stela of $s 3-w 3 d-h 3 t$ Preserved in the Grand Egyptian Museum with No.GEM 14376 "A Comparative Analytical Study and Publishing for the First Time"

- Hölzl, R. (2001). "Stelae", In: Redford, B. D. (Ed.), The Oxford Encyclopedia of Ancient Egypt", Vol. III, AUC Press, Cairo,319-324.

- Lang, H. \& Schäfer, H. (1902). Grab und Denksteine des Mittleren Reichs, 2Vols., Berlin. Vol.I,pp38-40,137, Vol.II,pp.112-113,143-144,349-353.

- Legrain., G., Statues et statuettes de rois et de Particuliers, vol. 3, Le Caire, 1916, p. 40.

- Mahmoud, D. (2005). Chairs and Benches in Ancient Egypt until the Late New Kingdom, M.A. thesis, Faculty of Archaeology, Cairo University, 24-26.

- Mariette, A.,(1880).Catalogue Géneral des Monuments d'Abydos découverts Pendant les Fouiles de cette Ville, Paris, pp. 418-419, nr. 1128.

- Martin, K. (1986). Stele, In: Helck, W. \& Otto, E. (Eds.), Lexikon der Ägyptologie, Vol.VI, Wiesbaden, Col.1.

- Maspero, G. (1908). Guide to the Cairo Museum, Cairo,p.85.

- Metawi, R. (2008). "The Stela of the Chief Interior-Overseer to the Treasurer Hrwnfr, Cairo Museum (CG 20563)", JARCE 44, pp.147-158.

- Müller, H. W,. "Die Totendensteine des Mittleren Reiches, ihre Genesis, ihre Darstellungen und ihre Komposition", MDAIK 4 (1933), 169-206

- Otto, E., (1975). Abydosfahrt, LÄ., I., col. 47.

- Radwan, A. (2003). History of Art in the Ancient World, Cairo.pp.50,79-98.

- Ragheb, A. (1996). The Lion in Ancient Egyptian Art, M.A. thesis, Tanta University, Egypt,p.156 sf.

- Ranke, H. (1935). Die Ägyptischen Personennamen,Vol.I, J.J.Augustin Press, Glückstadt,24/7,281/14,291/19,291/20,47/28,48/3,312/15, 315/25, 314/25, 48/3, 257/7, 290/21, 338/15, I 291/19, 181/7, 344/26, 312/15.

- Saad, Z. (1957). Ceiling stelae in Second Dynasty Tombs from the Excavations at Helwan, Cahier des Annales du Service des Antiquités de l'Egypte 21/ SAE, Le Caire, pp.3-5.

- Selim, H. (2001). Three Identical Stelae from the end of the Twelfth or Thirteenth Dynasty, ZÄS, vol. 29, pp.319-330-

- Shalaby, M., and Nassar, M. (2018). Unpublished Stela of Iii at Cairo Museum (CG 10232), SHEDET, Vol. 5, pp.96-108.

- Shoukry, M. (1958). The So-Called Stelae of Abydos. MDAIK, Vol. 16, 292-297. 
- Smither, P. (1939). The Writing of Htp di nsw in the Middle Kingdom and New Kingdom, JEA 25, pp.34-37.

- Stefanović, D. (2010). Four Middle Kingdom stelae, from the National Archaeological Museum, Athens, JEA, vol. 96, pp. 96-215.

- Tomich, A.I. (2017), From Work to Sanctuary the Production of Late Middle Kingdom Memorial Stelae, Middle Kingdom Studies 6, London, pp.21-22,152.

- Vandier, J. (1952). Manuel d' Archäologie Egyptienne II, Paris,pp.724-726.fig.4.

- Vercoutter, J. \& Castel, G. (1978). Supports de Meubles, éléments architectoniques, BIFAO, Vol. 78, pp.90-91.fig.7.

- Ward. W. A., Index of Egyptian Administrative and religious titles of the middle Kingdom, first publish by the American university of Beirut, Lebanon, (1982), $10 / 29$.

- Waziry, A. (2009). The Concept and Manifestations of Immortality in Ancient Egypt until the Late New Kingdom "A Cultural Linguistic Study", Ph.D. Dissertation, Faculty of Archaeology, Cairo University,pp.346-349,417-418.

- Westendorf, W. (1967). Beiträge aus und zu den MedizinischenTexten, ZÄS, vol. 92, pp.128-154.

- Wilkinson, R. (2007). The Complete Gods and Goddesses of Ancient Egypt, London, 180-181.

- Winlock, H. E., Bas-Reliefs from the Temple of Rameses II, at Abydos, New York 1921 , p. 15. 